Japan. J. Med. Sci. Biol., 35, 41-51, 1982

\title{
ASSAY IN MICE FOR MINUTE AMOUNTS OF ENDOTOXIN BY PRE-ADMINISTRATION OF LEAD ACETATE
}

\author{
Hiroshi FUJIWARA and KazUo KURATSUKA \\ Department of General Biologics Control, National Institute \\ of Health, Kamiosaki, Shinagawa-ku, Tokyo 141
}

(Received September 9, 1981. Accepted January 14, 1982)

\begin{abstract}
SUMMARY: The enhancing effect of pre-administration of lead acetate on the body-weight decrease due to endotoxin was studied in mice for the purpose of developing a method for determination of minute amounts of endotoxin. By adoption of the body-weight ratio on the first day after endotoxin administration $\left(\mathbf{B W R}_{1}\right)$ as a response, the linear regression lines of the dose-response were demonstrated over a wide range of log doses of several different endotoxin preparations tested. By use of these linear regression equations experimentally obtained, the minimum detectable dose was calculated. The minimum detectable dose was defined as a dose of an endotoxin preparation producing a mean body-weight response statistically distinguishable from that of the control. The doses obtained were mostly in nanogram order. The magnitude of the enhancement brought about by the lead treatment was estimated at about 40 to 100 times.
\end{abstract}

\section{INTRODUCTION}

The test for endotoxin contamination constitutes one of the important procedures for the quality control of biological products, blood products, parenteral drugs and medical devices. Recently, more and more items require assurance of freedom from endotoxin contamination; e.g., some vaccines (Mark et al., 1978), erythropoietin (Fumarola, 1977; Braun et al., 1979), cell tissue (Rickles et al., 1979), culture media (Martin et al., 1978), such medical instruments as catheters (Kundsin and Walter, 1980) etc. Since human beings are among the most sensitive species to endotoxin, the test for the safety of those products in respect to endotoxin should be as sensitive as possible. Rabbits are also sensitive to the toxic effects of endotoxin and the rabbit pyrogen test has been widely authorized and adopted in pharmacopoeia and minimum requirements in many countries (Ministry of Health and Welfare, 1973). However, the pyrogen test in rabbit is fairly troublesome for routine use, especially for the quantitative purposes. The limulus lysate test (Levin and Bang, 1964), which has recently become familiar in various fields, remains to overcome its drawback in the quantitative determination, though in sensitivity it seems to exceed any other method and its manipulation is simple. Therefore, it would be much convenient

藤原 博・倉塚和夫（国立予防衛生研究所 一般検定部） 
if a method for detection or quantitation of endotoxin, so simple as to be useful in routine work and as sensitive as the rabbit pyrogen test, was available.

Selye et al. (1966) reported that the lethality of the rat due to endotoxin was greatly enhanced by the iv administration of lead acetate. Since then, similar experimental results have been obtained in other animals than rats; e.g., mice (Seyberth et al., 1972; Terao and Katsuno, 1978), chickens (Truscott, 1969) and subhuman primate (Holper et al., 1973).

We noticed that the body-weight decrease in mice occurred with a much smaller dose than a lethal dose of endotoxin and started the study to establish a new assay method for small amounts of endotoxin by incorporating the enhancing effect of lead acetate into the determination of the body-weight decreasing activity instead of the lethal activity of endotoxin. As mice are relatively easy to handle, it is expected to develop a method with a sensitivity comparable to or rather higher than that of the rabbit pyrogen test and being convenient for routine use. Our experimental data obtained in the past with an E. coli endotoxin preparation (Kuratsuka and Fujiwara, 1972; Fujiwara and Kuratsuka, $1976,1978,1980)$ suggested a possibility of detecting endotoxin in the nanogram order by pre-administration of lead acetate.

In this paper, the sensitivity of this method for detection of small amounts of endotoxin will be presented with several endotoxin preparations.

\section{Materials ANd Methods}

Endotoxin: The endotoxin preparation mainly used was Escherichia coli LPS (lipopolysaccharide) (Control No. 613122, Difco Co., Detroit, MI) prepared by Westphal's method from $E$. coli $\mathrm{O} 111 \mathrm{~B} 4$ cells and designated as $E$. coli LPS (W). All but one preparations listed in Table II were purchased from Difco Co.; E. coli LPS (Y) was supplied by Yoshikawa (Yoshikawa and Fukumura, 1966). Each preparation was dissolved in sterilized distilled water $(1.0 \mathrm{mg} / \mathrm{ml})$ to make a stock endotoxin solution, which was autoclaved for $20 \mathrm{~min}$ at $120 \mathrm{C}$. From the stock solution, an endotoxin solution of an appropriate concentration was prepared by adding sterilized distilled water.

Lead acetate: Lead acetate (Lot No. 5283, Wako Junyaku Co., Osaka) was dissolved in sterilized distilled water $(100 \mathrm{mg} / \mathrm{ml})$; the solution was boiled for $15 \mathrm{~min}$ in a water bath. The solution was prepared just prior to use. From our previous studies (Kuratsuka and Fujiwara, 1974), used was a constant dose of $83 \mu \mathrm{g} /$ mouse of lead acetate, which enhanced the body-weight decrease due to endotoxin but had no effect by itself.

Diluent: Sterilized pyrogen-free distilled water was used for dilution of endotoxin and lead acetate solutions (Fujiwara and Kuratsuka, 1980). It was also used for lead acetate treatment of (Table II) and for endotoxin administration of control mice (Fig. 3, Table III).

Equipments: All glasswares including syringes, hypodermic needles, etc. were heated for $30 \mathrm{~min}$ at $250 \mathrm{C}$ to eliminate activities of possibly contaminating 
pyrogens.

Mice: Four-week-old female mice were purchased and weighed every morning for about 7 days. Those showing normal increase in body weight were randomly allotted to the materials and doses.

Body-weight-decreasing activity of endotoxin: As a metameter of bodyweight-decreasing activity of endotoxin, body-weight ratio on the first day $\left(\mathrm{BWR}_{1}\right)$ was adopted and calculated in each mouse by the following formula:

$$
\mathrm{BWR}_{1}=\frac{\mathrm{B}_{1}}{\mathrm{~A}} \times 100
$$

where $A$ and $B_{1}$ mean the body weight ( $g$ ) before and on the first day after endotoxin administration, respectively. The assumption that $\mathrm{BWR}_{1}$ normally distributes is based on empirical evidence.

Administration of lead acetate and endotoxin: Lead acetate was given an hour before endotoxin administration. Both were administered intraperitoneally in volumes of $0.25 \mathrm{ml}$ (Fujiwara and Kuratsuka, 1978).

Statistical analysis: Regression analysis and Finney's parallel line assay (1964) were carried out according to Kurokawa et al. (1978). Since the homoscedasticity of variances in each experiment was not denied by the Bartlett's or the Hartley's method, confidence intervals were calculated with the common variances for each experiment. The probability level was fixed at $5 \%$ and the confidence coefficient $95 \%$.

\section{RESULTS}

\section{Dose-response Regression Lines Including Minute Amounts of Endotoxin}

Five doses of serial 10 -fold dilutions of $E$. coli LPS (W), ranging from $0.0025 \mu \mathrm{g}$ to $25 \mu \mathrm{g}$ per mouse, were administered into each group of seven or eight lead-treated mice. A linear log dose-response line covered a wide range of doses of the preparation (Fig. 1). No death of mice was demonstrated even with the dose of $25 \mu \mathrm{g}$ per mouse. The minimum dose constituting the regression line was $0.0025 \mu \mathrm{g}$ per mouse. The $\mathrm{LD}_{50}$ of this preparation was approximately $500 \mu \mathrm{g}$ per mouse (unpublished data).

Subsequently, to determine whether the regression line including a dose as low as $0.0025 \mu \mathrm{g}$ per mouse can be regarded as linear, the following experiment was carried out. Eight doses of serial twofold dilutions of $E$. coli LPS (W) $(0.0025 \mu \mathrm{g}$ to $0.313 \mu \mathrm{g} /$ mouse) were administered into eight groups of seven leadtreated mice (Fig. 2). No significant deviation from linearity was demonstrated (Table I).

\section{Minimum Detectable Dose of Endotoxin by Pre-administration of Lead Acetate}

In the previous experiment, we used $0.0025 \mu \mathrm{g}$ of $E$. coli LPS (W) as the 


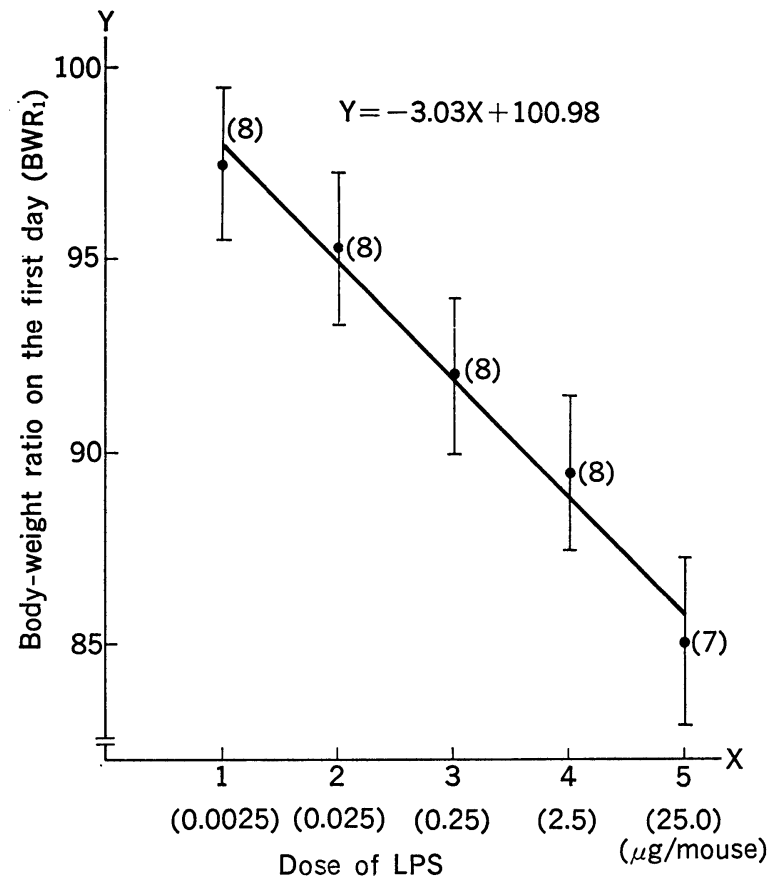

Fig. 1. Dose-response regression line in serial 10 -fold dilutions of endotoxin in mice preadministered with lead acetate.

Each point shows the mean $\mathbf{B W R}_{1}$ value at the indicated endotoxin dose. $\mathrm{X}$ in the formula and on the abscissa: $\mathrm{X}=\log \mathrm{D}-\log 0.00025$, where $\mathrm{D}$ is the actual dose $(\mu \mathrm{g} / \mathrm{mouse})$ of endotoxin. The figure in parentheses represents the number of mice per dose. The vertical bar represents the confidence interval of the mean at a $95 \%$ probability level. Lead acetate was administered an hour before endotoxin administration.

smallest dose (Figs. 1 and 2). Thereupon, we tried to find the minimum dose, of which mean value of $\mathbf{B W R}_{1}$ was significantly different from that of the control mice, not injected with endotoxin but treated with lead acetate. Thus, such a dose can be regarded as "the minimum detectable dose" of the preparation.

Each group of seven or 10 lead-treated mice was administered with each of serial twofold dilutions of $E$. coli LPS (W) $(0.00063 \mu \mathrm{g}-0.01 \mu \mathrm{g} / \mathrm{mouse})$ (Fig. 3). Another group of seven or 10 lead-treated mice was injected with distilled water for control. The $\mathrm{BWR}_{1}$ values and their $95 \%$ confidence limits were calculated for each group as shown in Fig. 3. Similar experiments were repeated three times. The difference in the mean of $\mathbf{B W R}_{1}$ was significant between the group administered with $0.00125 \mu \mathrm{g}$ of the endotoxin and that with water in Experiment 1 and also between the group administered with $0.0025 \mu \mathrm{g}$ and that with water in Experiments 2 and 3. Consequently, the minimum detectable dose of E. coli LPS (W) seems to have been between $0.00125 \mu \mathrm{g}$ and $0.0025 \mu \mathrm{g}$.

In each experiment, the experimental equation of dose-response line was obtained and the linearity was confirmed. By the equations, the $\mathrm{BWR}_{1}$ values 


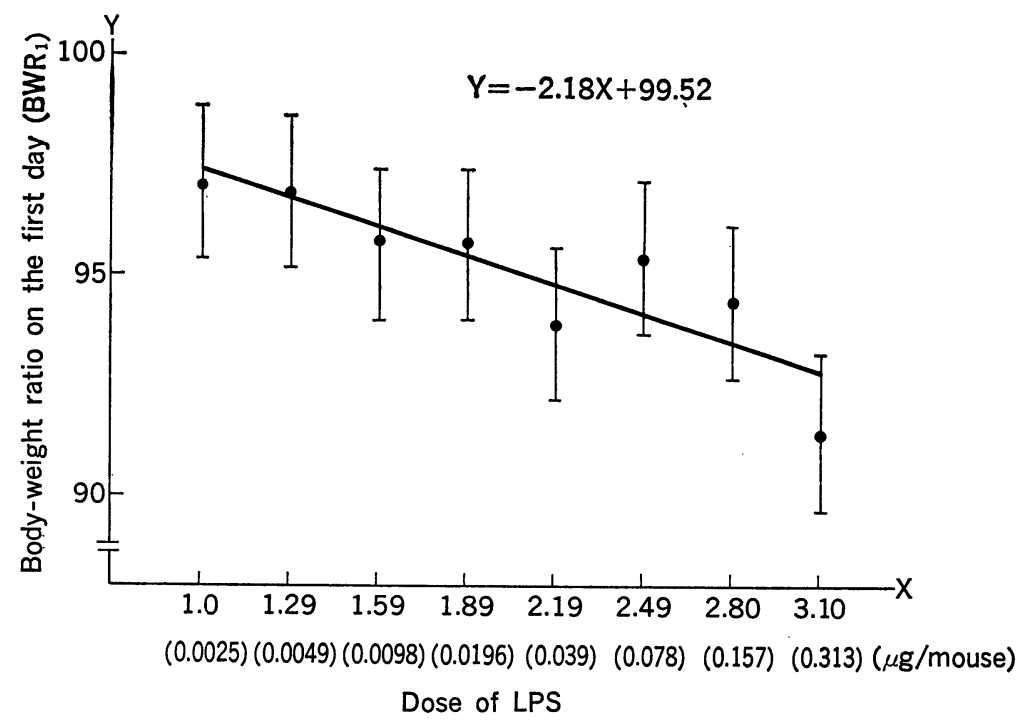

Fig. 2. Dose-response regression line in serial twofold dilutions of endotoxin in mice preadministered with lead acetate.

Seven mice were used for one dose. For the points, the vertical lines, lead acetate and log doses, see the legend for Fig. 1 .

\section{TABLE I}

Analysis of variance for the data presented in Fig. 2

\begin{tabular}{lrrrrr}
\hline Nature of variation & \multicolumn{1}{c}{ SS } & df & \multicolumn{1}{c}{ MS } & \multicolumn{1}{c}{ F } & F (0.05) \\
\hline Regression & 125.39 & 1 & 125.39 & 28.56 & 4.04 \\
Linearity & 39.75 & 6 & 6.63 & 1.51 & 2.30 \\
\hline Between doses & 165.14 & 7 & 23.59 & 5.37 & 2.21 \\
Error & 210.57 & 48 & 4.39 & & \\
\hline Total & 375.71 & 55 & & &
\end{tabular}

corresponding to two doses, $0.00125 \mu \mathrm{g}$ and $0.0025 \mu \mathrm{g}$, were calculated at 97.0 and 96.4 in Experiment 1,98.6 and 98.1 in Experiment 2 and 99.3 and 98.4 in Experiment 3, respectively. The mean of the six values was 97.97. From these data, the minimum detectable dose of $E$. coli LPS (W) was defined as the dose corresponding to 98 in terms of the BWR $_{1}$ value in these experiments.

\section{The Linear Relationship and the Minimum Detectable Doses of Several Endotoxin Preparations}

We studied the minimum detectable doses of six endotoxin preparations including $E$. coli LPS (W), being different one another in respect to the bacterial species and the purification processes. 


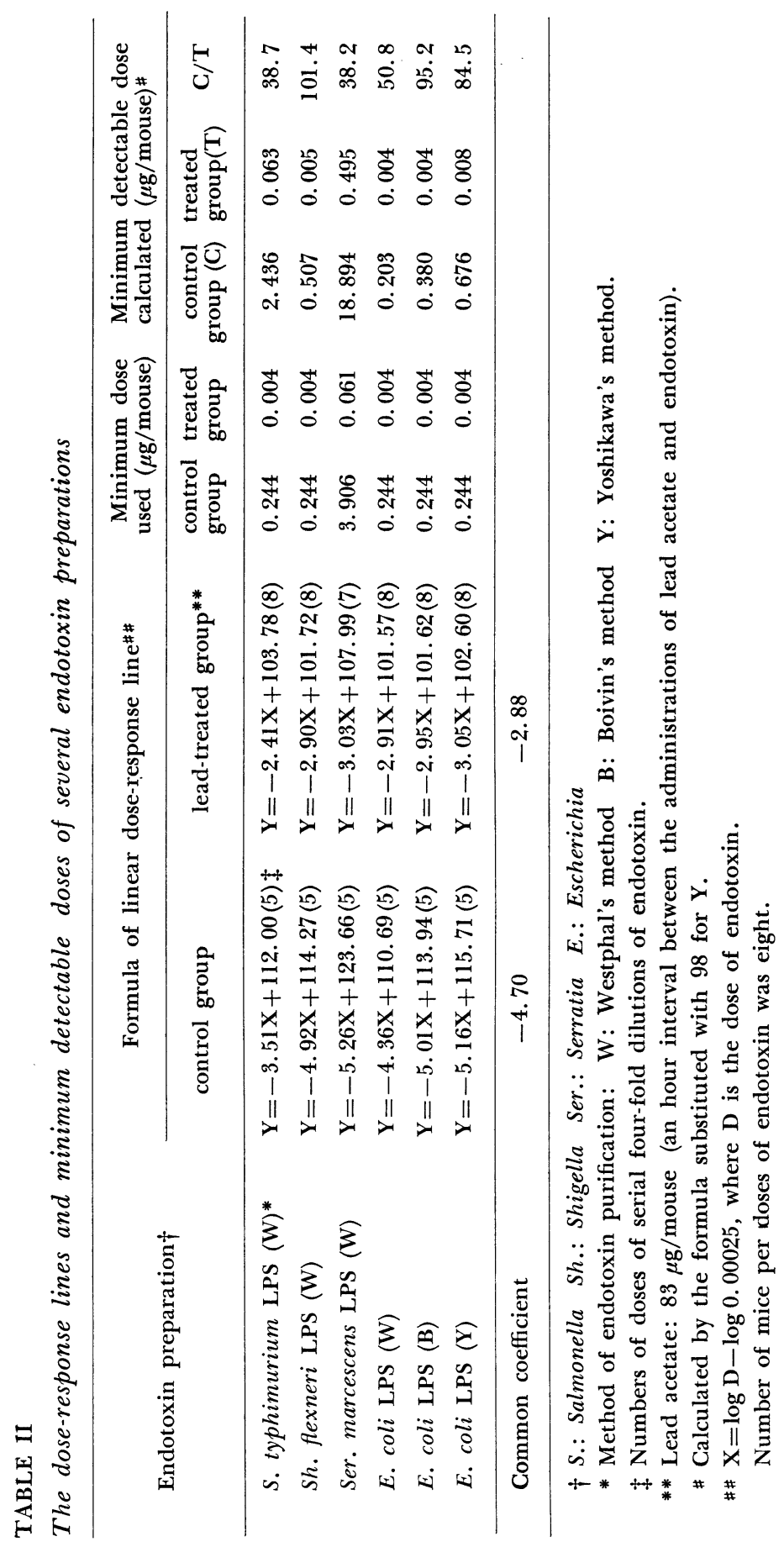




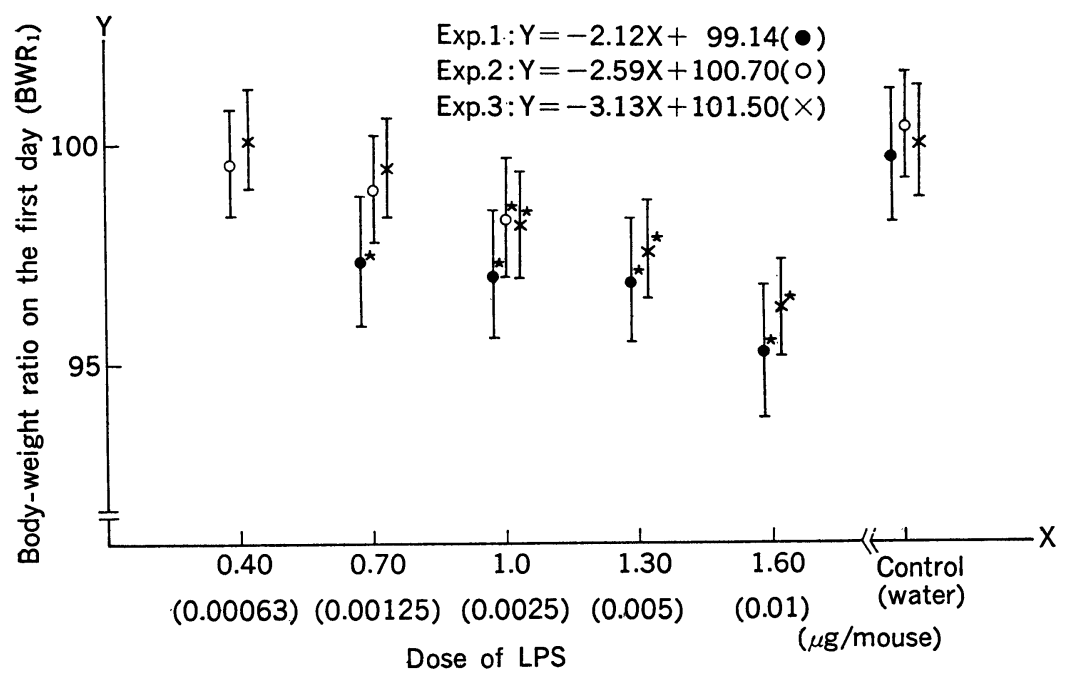

Fig. 3. The minimum detectable dose of endotoxin by pre-administration with lead acetate. Experiment $1(\bullet)$ : seven mice were used per dose of endotoxin. Experiments $2(0)$ and $3(\times)$ : 10 mice were used per dose of endotoxin. Control mice were administered with distilled water instead of endotoxin. *: Significantly different $(\alpha<0.05)$ from control. For the vertical lines, the points, lead acetate and log doses, see the legend for Fig. 1.

Four to eight doses, including one close to the expected minimum detectable dose (Table II), of serial fourfold dilutions of each preparation were administered into the lead-treated and the water-treated control groups. The formulae of the regression lines are presented in Table II. Among both of six regression coefficients in the lead-treated group and those in the water-treated control group, there was no significant difference. The regression lines in the lead-treated group were significantly flatter than those in the control groups as seen previously (Fujiwara and Kuratsuka, 1980).

As described in the preceding section, the dose corresponding to 98 in $\mathrm{BWR}_{1}$ value was defined as the minimum detectable dose of $E$. coli LPS (W). On the assumption that this relation is valid for the other endotoxin preparations, 98 was adopted provisionally as one of the response values to calculate the minimum detectable dose of the respective endotoxin preparations in the lead-treated mice. The doses of the six endotoxin preparations thus calculated by substituting 98 for $\mathrm{Y}$ in the respective formulae in lead-treated groups are shown in column $\mathrm{T}$ in Table II. These values were in the nanogram order in all but one preparation. The value thus obtained with, for instance, E. coli LPS (Y), was somewhat larger than the minimum dose used, $0.004 \mu \mathrm{g}$ per mouse, being within a range of linear regression.

The experiments for obtaining the $\mathrm{BWR}_{1}$ values for control mice injected with distilled water only (water-control in water-treated mice) were repeated six times. The results are shown in Table III. The mean $\mathbf{B W R}_{1}$ value (101.4) of the water control in water-treated mice was not different significantly from that 
TABLE III

Lower limit of $95 \%$ confidential interval in $\mathrm{BWR}_{1}$ of mice given water

\begin{tabular}{|c|c|c|c|c|c|c|c|}
\hline \multirow{2}{*}{$\begin{array}{l}\text { Response } \\
\left(\text { BWR }_{1}\right)^{*}\end{array}$} & \multicolumn{6}{|c|}{ Experiment No. } & \multirow{2}{*}{ Total } \\
\hline & 1 & 2 & 3 & 4 & 5 & 6 & \\
\hline mean & 102.9 & 101.4 & 99.6 & 102.1 & 101.1 & 100.5 & 101.4 \\
\hline variance & 3.91 & 3.16 & 10.27 & 2.99 & 11.66 & 7.73 & 6.78 \\
\hline$n \dagger$ & 12 & 10 & 8 & 10 & 10 & 10 & $60(10)$ \\
\hline lower limit** & 101.6 & 100.1 & 97.5 & 100.9 & 98.7 & 98.8 & $100.7(99.4)+$ \\
\hline
\end{tabular}

* Body-weight ratio on the first day (See the text).

** Lower limit of $95 \%$ confidential interval in $\mathbf{B W R}_{1}$.

$\dagger$ Number of mice used for statistical analysis.

Distilled water : $0.5 \mathrm{ml} / \mathrm{mouse} / \mathrm{ip}$.

$\$$ Lower limit at $\mathrm{n}=10$.

(99.9) of the three water controls in lead-treated mice shown in Fig. 3. No significant difference was demonstrated between the common variance of water control in water-treated mice (6.89) and that (3.51) of water control in leadtreated mice. In the experiments for the dose-response lines of $E$. coli LPS (W) shown in Table II, the homoscedasticity of variances in water-treated and leadtreated mice was not denied, either. Therefore, it may be justifiable to use the value of 98 in terms of $\mathbf{B W R}_{\mathbf{1}}$ for calculation of the minimum detectable dose also in water-treated mice. The estimates of doses calculated by substituting 98 for $\mathrm{Y}$ in the respective formula in water-treated groups are shown in column $\mathrm{C}$ in Table II. Then the ratios $\mathrm{C} / \mathrm{T}$ were calculated as an expression of the magnitude of the enhancement in the body-weight decrease due to endotoxin by lead acetate treatment as used in the present experiment (column $\mathrm{C} / \mathrm{T}$ in Table II). The values ranged from about 40 to 100 .

\section{Discussion}

The validity of the two kinds of the estimates obtained in the present experiment, the minimum detectable dose of endotoxin and the magnitude of enhancement by the lead acetate treatment, depends on the authenticity of the assumptions on which the calculations of the estimate were made.

One of the two assumptions is that the regression line is still linear within a range of doses close to the estimated minimum detectable dose. As the smallest dose used in each experiment was very close to the estimated minimum detectable dose (Table II) and no deviations from linearity of the regression line including the smallest dose was demonstrated, this assumption may be considered valid.

The other assumption is that the value of 98 in terms of $\mathrm{BWR}_{\mathbf{1}}$, adopted as the smallest mean response statistically distinguishable from mean $\mathbf{B W R}_{1}$ of the control mice, can be valid both in the lead-treated and in the water-treated control mice. This assumption is based on the findings that there was no significant difference in mean $\mathrm{BWR}_{1}$ or in the variance between the lead-treated 
TABLE IV

The minimum detectable doses calculated with 99 and 100 as $\mathrm{BWR}_{1}$ value in control mice and $\mathrm{C} / \mathrm{T}$ ratios

\begin{tabular}{lcccc}
\hline \multirow{2}{*}{$\begin{array}{c}\text { Endotoxin } \\
\text { preparation }\end{array}$} & \multicolumn{3}{c}{$\begin{array}{c}\text { Minimum detectable dose in control mice } \\
\text { with } \mathrm{BWR}_{1} \text { value }(\mu \mathrm{g} / \text { mouse })\end{array}$} \\
\cline { 2 - 5 } & $\mathrm{BWR}_{1}=99$ & $\mathrm{C}^{-\mathrm{T}^{*}}$ & $\mathrm{BWR}_{1}=100$ & $\mathrm{C} / \mathrm{T}^{*}$ \\
\hline S. typhimurium LPS (W) & 1.264 & 20.1 & 0.656 & 10.4 \\
Sh. flexneri LPS (W) & 0.317 & 63.4 & 0.199 & 39.8 \\
Ser. marcescens LPS (W) & 12.196 & 24.6 & 7.872 & 15.9 \\
E. coli LPS (W) & 0.120 & 30.0 & 0.071 & 17.5 \\
E. coli LPS (B) & 0.240 & 60.0 & 0.152 & 38.0 \\
E. coli LPS (Y) & 0.433 & 54.1 & 0.277 & 34.6 \\
\hline
\end{tabular}

* Ratio to the minimum detectable dose calculated with 98 in leadtreated mice shown in Table II.

For details see the footnote of Table II.

and the water-treated controls and that the difference in the variance between the lead treated-endotoxin injected mice and the water treated-endotoxin injected mice was not significant, either. The magnitude of the increase in the sensitivity largely depended on this assumption. To find the range of the magnitude, by the minimum detectable doses were recalculated in the same way as that in Table II using the values of 99 and 100 for the water-treated mice instead of the value of 98 and summarized in Table IV. Though the ratios $(\mathrm{C} / \mathrm{T})$ became fairly smaller than those in Table II, the magnitude of enhancement is still larger than 10.

The $\mathrm{LD}_{50}$ values in mice of partially purified endotoxin preparations were usually in the milligram order (Berczi et al., 1966), while the mouse bodyweight-decreasing doses of similar preparations were found to be in the submicrogram order (Ishida, 1968). The comparison of the lethal dose with the minimum dose inducing a detectable body-weight decrease in mice could also be made from the data given in Fig. 1, in which no death of mice occurred even by injection of $25 \mu \mathrm{g}$.

The minimum detectable dose of an endotoxin preparation of Serratia marcescens was much higher than those of other species. Such a difference might be due to the poor solubility in water or to the low purity of the preparation. Nevertheless, the magnitude of enhancement by the lead treatment was in a similar degree to that of endotoxin preparations of other species.

The specificity of the enhancing effect of lead acetate is an important factor when the test is to be used for detecting possible contamination of endotoxin in a given test sample. Selye et al. (1966) reported that among numerous reticuloendothelial blocking agents tested in rats, none equalled the sensitizing effect of lead acetate on the lethality. It remains still unsolved whether lead acetate affects the body-weight-decreasing activity of substances other than endotoxin. As an approach to the problem, the immunological method might be useful, since anti-endotoxin guinea-pig sera inhibited the body-weight-decreasing 
activity of endotoxin in mice (Kuratsuka and Shimazaki, 1973; Kuratsuka et al., 1973).

The six dose-response lines of the endotoxin preparations shown in Table II were parallel one another. This fact suggests that the parallel line assay method may be applicable to precise and reproducible micro-determination of endotoxin.

\section{Acknowledgement}

The authors wish to express their thanks to Dr. M. Kurokawa, ex-director of this Department, for his helpful advice.

\section{REFERENCES}

Berczi, I., Bertók, L. And Bereznai, T. (1966): Comparative studies on the toxicity of Escherichia coli lipopolysaccharide endotoxin in various animal species. Can. J. Microbiol., 12, 1070-1071.

Braun, J. L., Greenberg, H. M. And Robinson, S. H. (1979): Hemopoietic progenitor cells in short-term culture: Effects of erythropoietin and endotoxin contamination of erythropoietin preparations. Exp. Hematol., 7, 189-196.

Finney, D. J. (1964): Statistical method in biological assay. 2nd. ed., Charles Griffin and Co., London. $661 \mathrm{p}$.

Fujiwara, H. and Kuratsuka, K. (1976): Studies on lethal and bodyweight decreasing activities of lead acetate in mice. Comparative observations by intraperitoneal and intravenous injection. Medicine and Biology, 93, 461-465 (in Japanese).

Fujiwara, H. ANd Kuratsuka, K. (1978): Enhancement by lead acetate of the body-weightdecreasing activity of endotoxin. Pretreatment of lead acetate in mice. Medicine and Biology, 96, 385-388 (in Japanese).

Fujiwara, H. And Kuratsuka, K. (1980): Enhancement by lead acetate of body-weight-decreasing activity of endotoxin: Quantitative comparisons of some administration methods of lead acetate. Japan. J. Med. Sci. Biol., 33, 203-216.

Fumarola, D. (1977): Endotoxin contamination of some erythropoietin preparations: An emerging question. Blood, 50, 548-549.

Holper, K., Trejo, R. A., Brettschneider, L. And di Luzio, N. R. (1973): Enhancement of endotoxin shock in lead-sensitized subhuman primate. Surg. Gynecol. Obstet., 136, 889-893.

IsHidA, S. (1968): Characterization of the body weight-decreasing toxicities in mice by the lymphocytosis-promoting factor and the heat-labile toxin of $B$. pertussis and endotoxin. Japan. J. Med. Sci. Biol., 21, 115-135.

Kundsin, R. B. And Walter, C. W. (1980): Detection of endotoxin on sterile catheters used for cardiac catheterization. J. Clin. Microbiol., 11, 209-212.

Kuratsuka, K. And FujIwara, H. (1972): Change of sensitivity to body weight decreasing activity of endotoxin by treatment with lead acetate in mice. Japan. J. Bacteriol., 27, 827 (in Japanese).

Kuratsuka, K. And Fujiwara, H. (1974): Enhancement by lead acetate of the body weightdecreasing activity of endotoxin. Mixed administration of lead acetate and endotoxin in mice. Medicine and Biology, 89, 11-14. (in Japanese).

Kuratsuka, K. AND Shimazaki, Y. (1973): The suppressive effect of the sera of the guinea pigs immunized with the typhoid and paratyphoid combined vaccine on the body weight-decreasing toxicity of the vaccine. Japan. J. Bacteriol., 28, 297 (in Japanese).

Kuratsuka, K., Shimazaki, Y. AND Funasaka, I. (1973): Determination of the activity against the body weight-decreasing toxicity of the typhoid and paratyphoid combined vaccine in the sera of the guinea pigs immunized with the vaccine. Japan. J. Bacteriol., 28, 297 (in Japanese).

Kurokawa, M., TaKahashi, K. AND Ishida, S. (1978): Bioassay. Kindai Shuppan, Tokyo (in Japanese). $303 \mathrm{p}$.

Levin, J. And Bang, F. B. (1964): The role of endotoxin in the extracellular coagulation of 
limulus blood. Bull. Johns Hopkins Hosp., 115, 265-274.

Mark, R. G., Stanbro, H. and Merril, C. R. (1978): Endotoxins in commercial vaccines. Appl. Environ. Microbiol., 36, 445-449.

Martin, F., Martin, M., Jeannin, J. F. and Lagneau, A. (1978): Rat macrophage-mediated toxicity to cancer cells: effect of endotoxins and endotoxin inhibitors contained in culture media. Eur. J. Immunol., 8, 607-611.

Ministry of Health and Welfare, Japanese Government (1973): Minimum Requirements for Biological Products. p. 243-244, English edition.

Selye, H., Tuchweber, B. ANd Bertók, L. (1966): Effect of lead acetate on the susceptibility of rats to bacterial endotoxins. J. Bacteriol., 91, 884-890.

Rickles, F. R., Levin, J., Rosenthal, D. I. ANd Atkins, E. (1979): Functional interaction of concanavalin A and bacterial endotoxin (lipopolysaccharide): effects of the measurement of endogenous pyrogen release, human mononuclear cell tissue factor activation, lymphocyte DNA synthesis, and gelation of Limulus amebocyte lysate. J. Lab. Clin. Med., 93, 128-145.

Seyberth, H. W., Schmidt-Gayk, H. and Hackenthal, E. (1972): Toxicity, clearance and distribution of endotoxin in mice as influenced by actinomycin $\mathrm{D}$, cycloheximide, $a$-amanitin and lead acetate. Toxicon, 10, 491-500.

Terao, K. And Katsuno, M. (1978): Quantitative biological assay of small amounts of endotoxin with lead-treated mice. Medicine and Biology, 96, 227-231 (in Japanese).

Truscott, R. B. (1969): Endotoxin studies in chicks. Can. J. Comp. Med., 34, 134-137.

Yoshikawa, T. and Fukumura, K. (1966): On the biological activities of endotoxin isolated from Bordetella pertussis and Escherichia coli. Japan. J. Bacteriol., 22, 232 (in Japanese). 